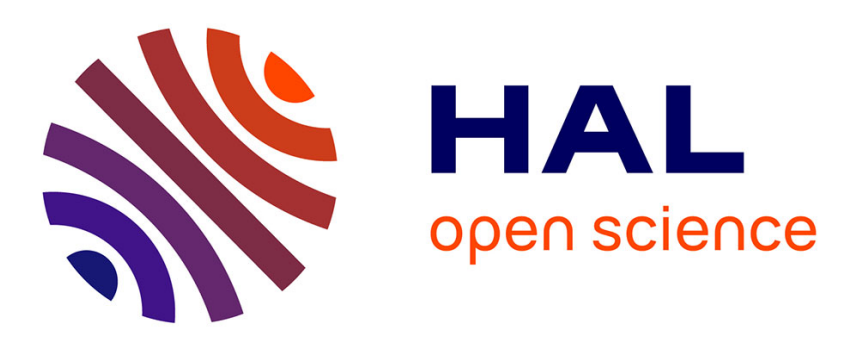

\title{
The Monviso ophiolitic massif (Western Alps), a section through a serpentinite subduction channel.
}

\author{
Stéphane Guillot, S. Schwartz, K. Hattori, A. Auzende, J. Lardeaux
}

\section{To cite this version:}

Stéphane Guillot, S. Schwartz, K. Hattori, A. Auzende, J. Lardeaux. The Monviso ophiolitic massif (Western Alps), a section through a serpentinite subduction channel.. Journal of the Virtual Explorer, 2004, 16, 17 p. hal-00103165

\section{HAL Id: hal-00103165 \\ https://hal.science/hal-00103165}

Submitted on 5 Oct 2006

HAL is a multi-disciplinary open access archive for the deposit and dissemination of scientific research documents, whether they are published or not. The documents may come from teaching and research institutions in France or abroad, or from public or private research centers.
L'archive ouverte pluridisciplinaire HAL, est destinée au dépôt et à la diffusion de documents scientifiques de niveau recherche, publiés ou non, émanant des établissements d'enseignement et de recherche français ou étrangers, des laboratoires publics ou privés. 


\title{
The Monviso ophiolitic Massif (Western Alps), a section through a serpentinite subduction channel
}

\author{
S. GUILLOT ${ }^{1-2}$, S. SCHWARTZ ${ }^{2}$, K. H. HATTORI ${ }^{3}$, \\ A.L. AUZENDE ${ }^{4}$, J.M. LARDEAUX ${ }^{5}$ \\ ${ }^{1}$ Laboratoire de Sciences de la Terre, UCB et ENS-Lyon, CNRS, Lyon, France \\ sguillot@univ-lyon1.fr \\ ${ }^{2}$ Maison des Géosciences, OSUG, CNRS, Grenoble, France \\ ${ }^{3}$ Ottawa-Carleton Geoscience Centre, University of Ottawa, Ottawa, Canada \\ ${ }^{4}$ Laboratoire de Minéralogie-Cristallographie, CNRS, IPGP, Paris, France \\ ${ }^{5}$ Géosciences Azur, Université de Nice, CNRS, Nice, France
}

\begin{abstract}
The exhumation of subducted lithosphere requires a mechanically weak zone at the interface between the subduction plane and the rigid overlying mantle peridotites with a viscosity greater than $10^{20}$ Pa.s. At shallow depths $(<40-50 \mathrm{~km})$ blueschists are exhumed in accretionary wedge along the interface between the subducting plate and the overriding plate (Platt, 1993). At greater depth, serpentinites plays the role of mechanically weak layer in cool continental subduction and act as the lubricant and produce a return flow for the exhumation of eclogitic rocks. The close association of serpentinites and eclogites in the Monviso massif (Western Alps) allow to discuss the concept of subduction serpentinite channel. We propose that the Monviso ophiolitic massif corresponds to a section of a $50 \mathrm{~km}$ long serpentinite channel in where eclogitic blocks were exhumed between 60 and $45 \mathrm{Ma}$ and ended when the European continental margin was involved in the southeast dipping subduction zone.
\end{abstract}

\section{Introduction}

High pressure (HP) to ultra high pressure (UHP) rocks in modern orogenic belts have been interpreted as part of subducted oceanic or continental plates (Ernst, 1999; Eide and Liou, 2000; Guillot et al., 2003). The exhumation of subducted lithosphere requires a mechanically weak zone at the interface between the subduction plane and the rigid overlying mantle peridotites with a viscosity greater than $10^{20}$ Pa.s (Hirth and Kohlstedt, 2003). At shallow depths $(<40-50 \mathrm{~km})$ blueschists are exhumed in accretionary wedge along the interface between the subducting plate and the overriding plate (Platt, 1993). Hydrated sediments at the base of the accretionary wedge can develop a corner flow due to their low viscosity $\left(<10^{19}\right.$ Pa.s; Cloos and Schreeve, 1988), which facilitates the exhumation of blueschists during the active subduction of oceanic plate (Platt, 1986). This is the case for the Franciscan complex in California (Platt, 1986: Cloos and Schreve, 1988), the northern Carribean complex in Cuba and Dominican Republic (Goncalvez et al., 2000; Garcia-Casco et al., 2002) and the External Piemont zone (Schistes Lustrés units) in the Western Alps (Schwartz, 2001, Agard et al., 2002).

At greater depth, an accretionary wedge is pinched out and the abundance of sediments significantly decreases, yet the exhumation of eclogitic rocks is rapid (Duchêne et al., 1997). Therefore, a different mechanism is necessary for the exhumation of eclogitic rocks. Proposed processes for the exhumation of HP to UHP rocks vary depending on the tectonic settings. 
They may be classified into three end-members. (1) Partial melt provides a low viscosity layer in high temperature continental subduction, such as western Norway (Labrousse et al., 2002) and Dabie Shan in China (Hacker et al., 2000) (2) Serpentinites and/or phengite- bearing rocks plays the role of mechanically weak layer in cool continental subduction, such as the Tso Morari in Himalaya and Dora Maira in the Alps (Guillot et al., 2001; de Sigoyer et al., 2004; Chopin and Schertl, 1999). Their exhumation is likely assisted by low density of eclogitized continental rocks (Chemenda et al., 1996). (3) The exhumation involves eclogitized oceanic or arc-related mafic rocks. This is only documented in few places, such as Alpine belt of Cuba (Zaza zone) (Auzende et al., 2002; Garcia-Casco et al., 2002) and the Kohistan arc in Pakistan (Le Fort et al., 1997). Rare occurrences of eclogitized mafic rocks are not surprising considering high density of eclogitized mafic rocks $\left(3500 \mathrm{~kg} \cdot \mathrm{m}^{-3}\right.$ ) compared to the mantle peridotites $\left(3300 \mathrm{~kg} \cdot \mathrm{m}^{-3}\right)$. The negative density difference requires boundary forces to compensate the gravity force.

Eclogites are commonly accompanied by serpentinites. Some serpentinites are considered to have been exposed on the oceanic floor before the subduction (Scambelluri et al., 1995; Li et al., 2004). The second type of serpentinites is hydrated peridotites at the base of mantle wedges (Guillot et al., 2000, 2001). These serpentinites may replace the role of hydrated sediments at greater depths and act as the lubricant and produce a return flow for the exhumation of eclogitic rocks. This proposal is supported by the systematic occurrence of serpentinites spatially associated with eclogitic rocks derived from oceanic crust in the Alps (Hermann et al., 2000; Schwartz et al., 2000, Li et al., 2004), in Cuba (Auzende et al., 2002; Garcia-Casco et al., 2002 ) and in Kohistan (Le Fort et al., 1997).

The aim of this paper is to describe the occurrence of serpentinites and eclogites in the Monviso massif (Western Alps), the origin of serpentinites, and the geometry and mechanisms for the exhumation of the eclogitized oceanic crust during the active subduction.

\section{Geological setting}

The southern part of the Piemont zone of the Western Alps (Figure 1) consists of three major tectono-metamorphic units (Figure 2) coming from the Piedmont-Liguria domain of the Western Tethys that was active spreading during the Upper Jurassic period (e.g. Lombardo et al, 2002 for review) and closed in the Late Cretaceous to Early Tertiary (e.g. Agard et al., 2002; Schettino and Scotese, 2002). The uppermost unit (Chenaillet massif) consists of a weakly metamorphosed ophiolite obducted onto the the European continental margin (Mével et al., 1978). The intermediate unit corresponds to the External Piedmont zone, namely the Schistes Lustrés units (Deville et al., 1992). It consists of metric to kilometric lenses of ophiolitic blocks embedded in dominant Jurassic to Lower Cretaceous clastic metasedimentary rocks (Lagabrielle et al., 1984; Lemoine et al., 1987). They are metamorphosed to blueschist facies conditions during the period from 75 to 40 Ma (Deville, 1986; Schwartz, 2001; Agard et al., 2002; Schettino and Scotese, 2002) and commonly considered as an accretionary wedge that are later tilted during the Alpine collision (Tricart et al., 2004). The maximum thickness of the wedge during its deposition is calculated to be between 40 to $65 \mathrm{~km}$ pending of the pressure estimates on blueschists (Schwartz et al., 2001; Agard et al., 2002). The maximum thickness of $65 \mathrm{~km}$ is probably overestimated as it is essentially based on not-well constrained thermodynamic data of phengite (Vidal et al., 2001). 


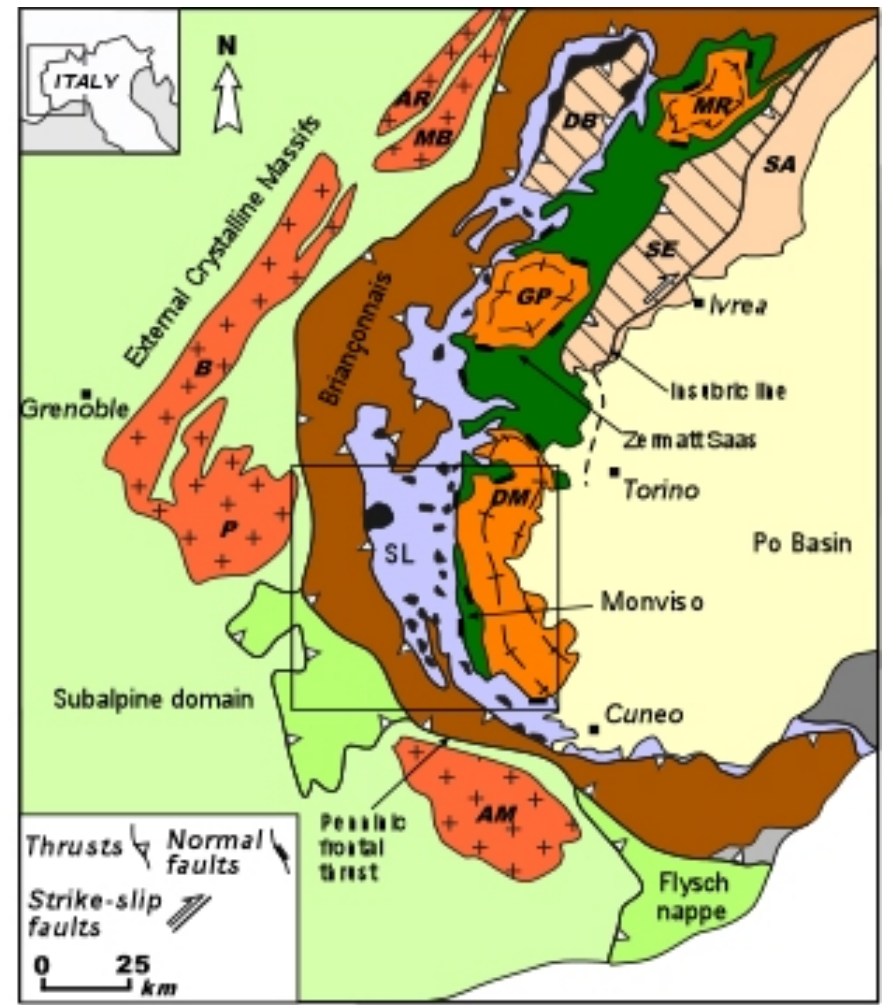

Figure 1. Map of the Western Alps showing the main tectonic units, modified after Polino et al. (1990). AM: Argentera-Mercantour, AR: Aiguilles Rouges, B:Belledonne, DB : Dent-Blanche, DM : Dora Maira, GP : Gran Paradiso, MB : Mont-Blanc, MR : Monte Rosa, P : Pelvoux, SA : South Alps, SE : Sezia, SL : Schistes Lustrés.

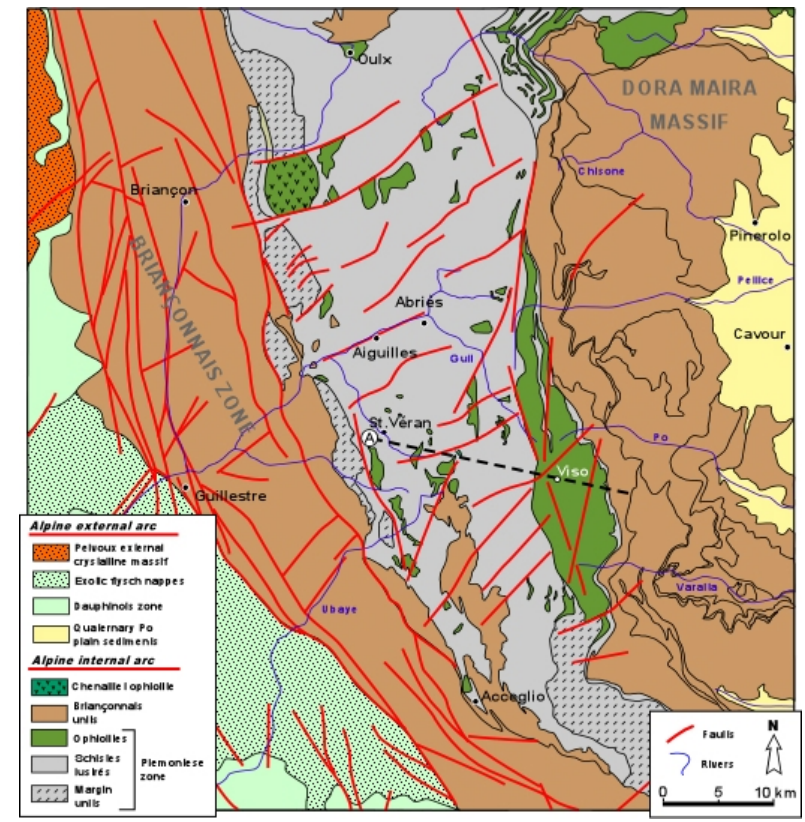

Figure 2. Detailed geological map of the studied area showing the relationships between the Monviso ophiolite with their surrounding units (after Schwartz, 2000). 
Monviso ophiolitic massif, $35 \mathrm{~km}$ NS and $35 \mathrm{~km} \mathrm{EW}$, forms the structural base of the unit (Figure 3) and is separated from the blueschist "Schistes Lustrés" by a ductile normal fault within the western serpentinite unit (Traversetta unit) (Ballèvre et al., 1990) and to the east from the continental Sampeyre and Dronero units of the Dora Maira massif by a second normal ductile fault (Blake and Jayko, 1990).

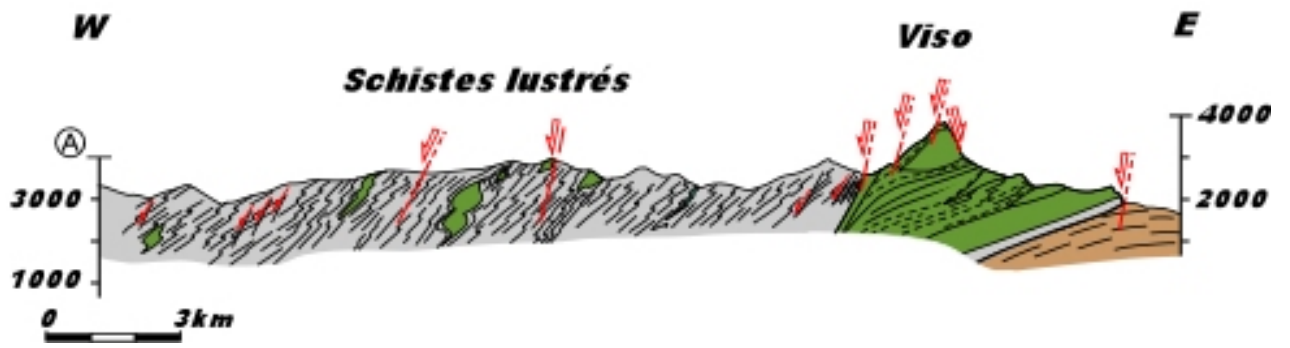

Figure 3. Schematic vertical sections across the studied area from the Briançonnais to the Dora Maira units (After Schwartz, 2000).

Geophysical data shows the root of this massif at a depth of about $10 \mathrm{~km}$ (Schwartz, 2001; Paul et al., 2001; Figure 4). The root of this unit in the eastern part is buried below the Tertiary sediments of Po Plain. However, northward along the Gran Paradiso or Monte Rosa transects, the ophiolitic unit has a vertical extension along the Insubric line (Escher et al., 1997). The evidence suggests that the Monviso unit likely extends vertically east of the Dora Maira massif (Figure 4).

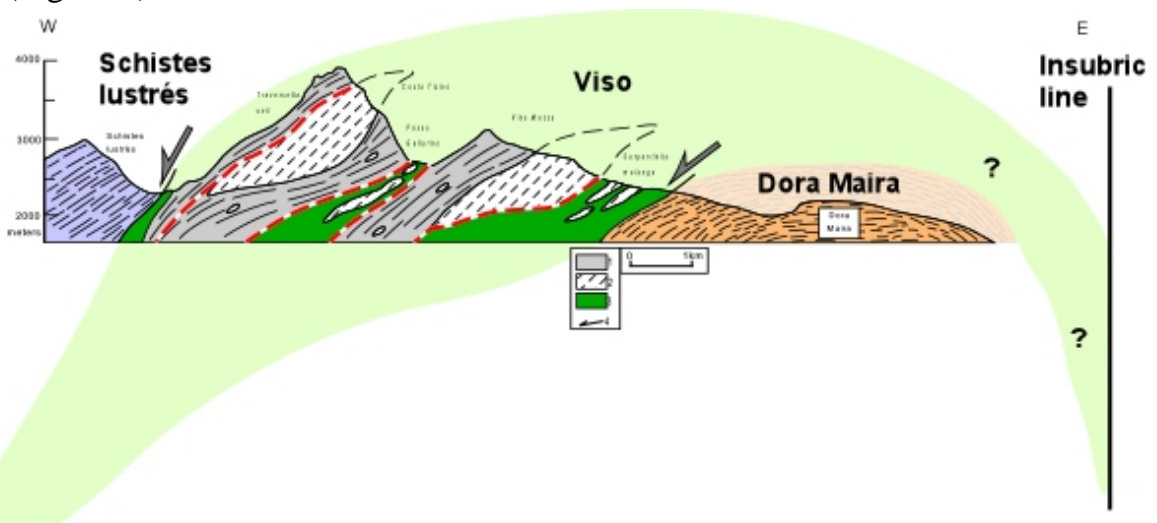

Figure 4. Cross section of the Monviso ophiolite showing the different units with eclogitic lenses embedded within the serpentinite. The tectonic contact between the different units correspond to normal shear zones under greenschist facies conditions. 1: Greenschist foliated metabasalts (prasinites); 2: eclogitic lenses composed of undifferentiated metagabbros, massive metabasalts and pillow lavas; 3 serpentinites. The shaded envelop corresponds to the geometry of the Monviso unit rooted below the Schistes Lustrés (Paul et al., 2001) and possibly rooted east of the Dora Maira massif, along the Insubric line.

In the central part of the massif, the Monviso massif comprised of six distinct westdipping tectono-metamorphic units of metabasalts or metagabbroic lenses, each of which is separated by west dipping normal shear zones in the serpentinite matrix (Figure 4 and Figure 5) Each unit records different eclogitic facies metamorphic condition between 1.2 and 2.6 GPa and retrogressed under similar blueschist facies conditions of about $0.7 \mathrm{GPa}$ and $420^{\circ} \mathrm{C}$ 
(Lombardo et al., 1978; Philippot, 1990; Blake et al., 1995; Schwartz et al., 2000; Lombardo et al., 2002)(Figures 6 and 7).

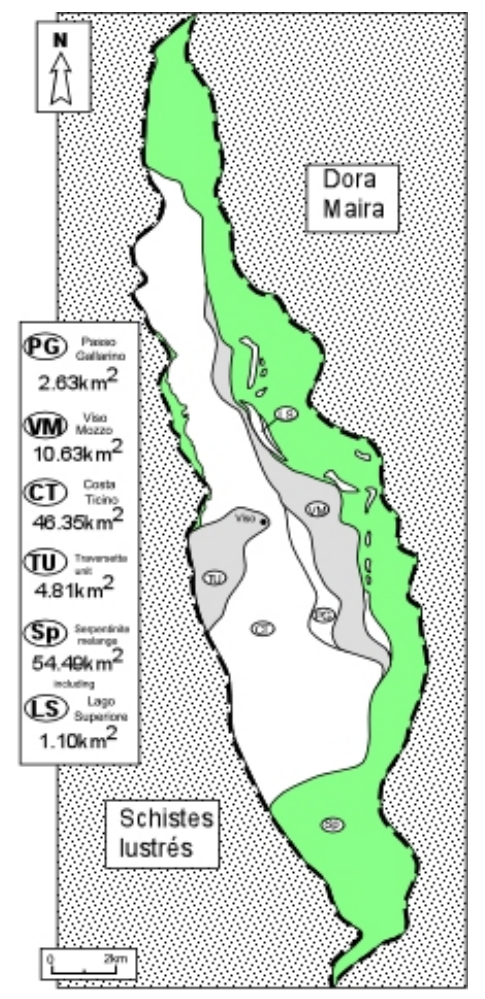

Figure 5. Schematic geological map of the Monviso unit after Blake et al. (1995) and Schwartz et al. (2001) showing the relationships of main tectonic units. The boundaries are estimated by image analysis. Notice that the serpentines (SP) represent about $50 \%$ of the total surface area and caps (OR overlies) all the eclogitic units. CT= Costa Ticino, LS= Lago Superiere. PG=Passo Gallarino, VM=Viso Mozzo.

The age of the eclogitization variest. The Lago Superior unit yielded a Sm-Nd isochron age of $61 \pm 10$ Ma from garnet + omphacite (Cliff et al., 1998), a Lu-Hf isochron age of $49 \pm 1$ (Duchêne et al., 1997), and a U-Pb zircon age of $45 \pm 1$ Ma by Rubatto and Hermann (2003). These ages are comparable to Ar-Ar age of $50 \pm 1$ Ma (Monié and Philippot, 1989). The exhumation rate of the unit was estimated by Schwartz et al (2000). It was fast at the beginning $\left(1 \mathrm{~cm} \cdot \mathrm{yr}^{-1}\right)$ and slowed at the blueschist to greenschist-facies transition $\left(1 \mathrm{~mm} \cdot \mathrm{yr}^{-1}\right)$. 


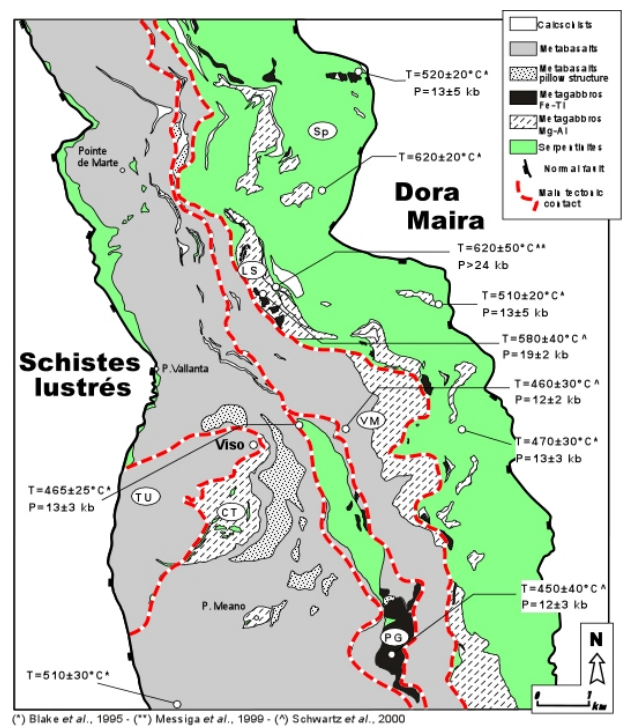

Figure 6. Geological map of the central part of the Monviso, after Schwartz et al., (2001). The P-T estimates on the eclogite facies conditions are from Blake et al. (1995), Messiga et al., (1999) and Schwartz et al. (2000).

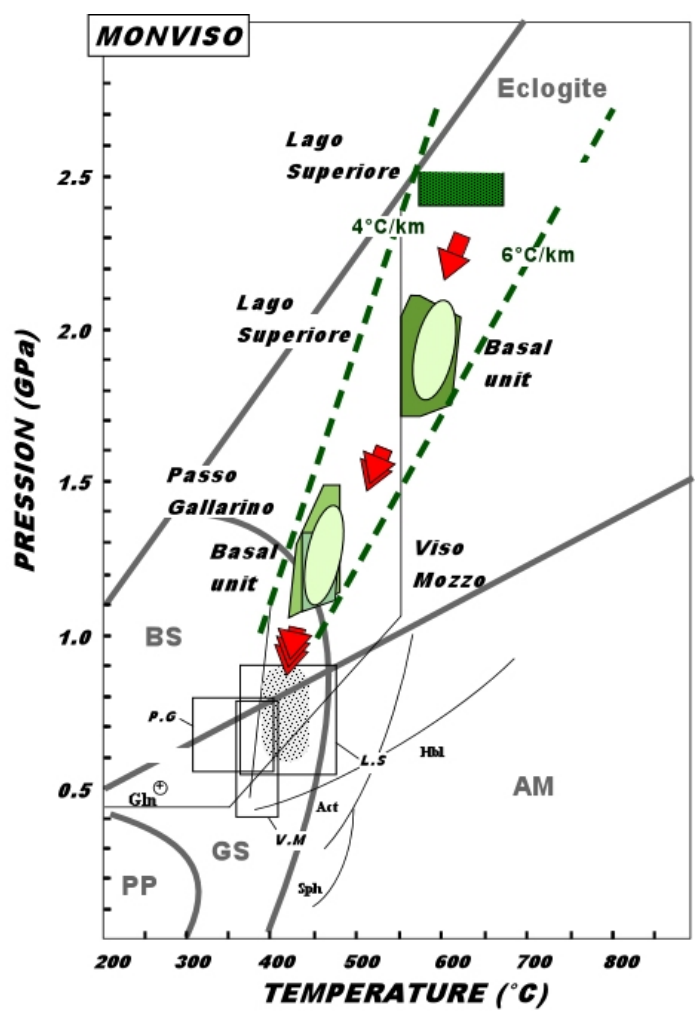

Figure 7 : P-T paths of eclogitic units in Monviso, showing that different units show similar retrogression paths under blueschist facies conditions. Note that the P-T pathes yield the geothermal gradients of 4 to $6^{\circ} / \mathrm{km}$, typical of subduction zone conditions. 
The basal serpentinite unit is 400 meters in thickness. The serpentinites have lherzolitic protolith with only minor harzburgite and dunite, and is cut by sheared dykes of rodingitized gabbro and basalt. The serpentinite layer commonly contains metric to hectometric lenses of foliated eclogitic gabbro, ferrogabbro and metamorphosed plagiogranite. These lenses are tectonically incorporated as tectonic melange and they show widely different metamorphic conditions; from $1.3 \mathrm{GPa}$ and $470{ }^{\circ} \mathrm{C}$ to $2.0 \mathrm{GPa}$ and $575^{\circ} \mathrm{C}$ (Blake et al., 1995; Schwartz et al., 2000; Castelli et al., 2002). Considering the geometry, this basal serpentinite unit likely had an initial size of about $50 \mathrm{~km}$ x $10 \mathrm{~km}$ (Figure 4).

The Lago Superiore unit is a discontinuous layer of intensely deformed and recrystallized metagabbros with local occurrences of chromian omphacite (smaragdite gabbro). The metagabbros hosts small bodies of ultramafic cumulates and hydrated mantle peridotites (Messiga et al., 1999). This unit recorded the highest pressure and temperature conditions of $2.4 \mathrm{GPa}$ and $620 \pm 50^{\circ} \mathrm{C}$ in Cr-rich magnesiochloritoid-bearing eclogites.

The Viso Mozzo unit consists of greenschists and banded glaucophane-epidote metabasalts with local preservation of pillow lava structure (Lombardo et al., 2002). Metric eclogitic lenses are embedded in the strongly foliated metabasalts, recording pressure-temperature conditions of $1.2 \pm 0.2 \mathrm{GPa}$ and $460 \pm 30^{\circ} \mathrm{C}$ (Schwartz et al., 2000). In the upper part of the unit, outcrops thin layers of carbonate micaschists (Schistes lustrés) interbedded with the metabasites.

The Passo Gallarino unit is a $100 \mathrm{~m}$ thick layer of eclogite and omphacite-bearing metagabbro $\left(1.3 \pm 0.3 \mathrm{GPa}, 450 \pm 40^{\circ} \mathrm{C}\right)$ hosted in sheared serpentinites associated with quartzite and mica schist. This unit is characterized by intense syn-eclogitic shearing (Lardeaux et al., 1986) superimposed by flattening under blueschist facies conditions (Schwartz et al., 2000).

The Costa Ticino unit is the thickest unit ( 1.2 km) and composed from the base to the top of basalt breccia, pillow lavas, metagbbro and slices of serpentinites, that have been metamorphosed under blueschist facies conditions $\left(\sim 0.7 \mathrm{GPa}, \sim 420^{\circ} \mathrm{C}\right.$ ) (Lombardo et al., 1978).

The Vallanta unit structurally overlies the Costa Ticino unit. It is also an eclogitic unit that consists of fine-grained metabasalts, carbonate-bearing mica schist and serpentinites. Metamorphic conditions are not available for this unit.

\section{Origin of the Monviso ophiolitic massif}

The Monviso ophiolitic massif is characterized by the alternation of tectonic units dominated by thick metabasalts with N-MORB geochemical signatures and Mg- and Fe-rich tholeitic metagabbro, (Lombardo et al., 1978; MONVISO, 1980). Basal serpentinite-rich unit appears to have originated from lherzolite and overlain by a thin sedimentary sequence (Lemoine, 1980). The assemblage of basalt-rich and -poor units is similar to the lithology of low spreading oceanic lithosphere, such as the Mid Atlantic Ridge and the Indian ocean (Lagabrielle and Cannat, 1990; Mevel, 2003). This appears to be supported by $\delta \mathrm{O}^{18}$ values between 3.0 to $5.3 \%$ and $\mathrm{NaCl}$ equivalent salt contents of 17 to $21 \mathrm{wt} \%$ for Monviso omphacite (Nadeau et al., 1993), and typical of HT oceanic hydrothermalism signature?? (Philippot et al., 1998). $\delta \mathrm{O}^{18}$ and salinity can support either hydration in the mantle wedge at 
high temperature or on the ocean floor. It rejects the hydration at low temperatures on the ocean floor because low temperature hydration yield high $\delta \mathrm{O}^{18}$ values.

These units are interpreted as fragments of the Piedmont domain of the Western Tethys ocean during the Upper Jurassic and subucted during the Paleocene-Eocene. Recent U-Pb zircon ages show that the age of the magmatic activity range between $163 \pm 2 \mathrm{Ma}$ and $152 \pm 2$ Ma (Rubatto and Hermann, 2003; Lombardo et al., 2002). Lombardo et al. (2002) noted this short duration of igneous activity in the Monviso massif and also a short time span (from $c a$ 170 to $c a 150 \mathrm{Ma}$ ) for the entire Piedmont-Liguria Tethys and suggested an embryonic ocean (max 380 km; Piccard et al., 2001; Schettino and Scotese, 2002) rather than a mature, slow spreading, Atlantic-type ocean model (Lagabrielle and Cannat, 1990). Blake et al. (1995) and Schwartz et al. (2001) suggested that part of the serpentintes represent hydrated peridotites at the base of mantle wedge, as observed in the Himalaya (Guillot et al. 2001). This is supported by the bulk composition of serpentinites, which show refractory character, similar to those from the Himalayas (our unpublished data).

\section{Microstructural study of the serpentinite}

The serpentinites represent about $40 \%$ of the Monviso ophiolitic massif (e.g., Lagabrielle, 1987; Blake et al.,1995; Schwartz et al. 2001) (Figure 5). Serpentinites are particularly well exposed in the Lago Superiore, Passo Gallarino and Viso Mozzo units. The intimate association of serpentinites with the eclogites from the $\mathrm{cm}$ to cartographic scale suggest that they shared similar metamorphic evolution. The orientation and the sense of shear observed in the serpentinite matrix are similar to those observed in the surrounding metabasites with top to the west under greenschist facies metamorphic conditions (Schwartz et al., 2000; 2001).

The serpentinites observed in the Monviso unit are mostly hydrated close to $100 \%$ and few samples show relict diopside grains which are highly chloritized and deformed. Serpentinites show penetrative foliation with locally pseudomorphic textures. Pseudomorphic
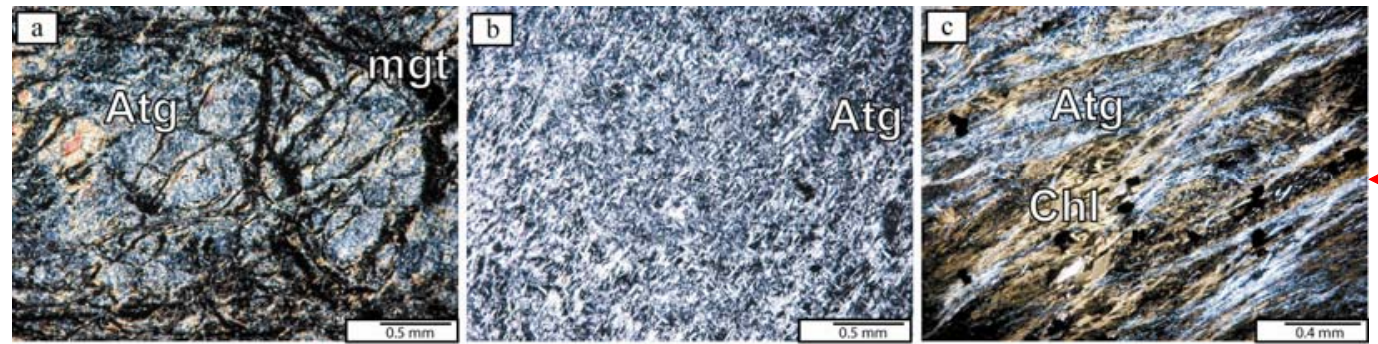

Figure 8. Photomicrographs of serpentinites from Monviso under cross-polarized light after Auzende et al. (2005). a) Interpenetrative antigorite surrounded by fine grained magnetite that outlines the pseudomorph of olivine (Sample 624-2 : Viso Mozzo), b) Typical antigorite interpenetrative texture in metabasalt? (Sample 6233: Lago Superiore), c) Sheared serpentinite where antigorite and chlorite (Chl) define the foliation Postkinematic chlorite crystals cut the foliation (Sample 625-6 : Lago Superiore).

structures are observed with relict magnetites that still underline early mesh boundaries* whereas former pyroxenes (bastites) correspond to magnetite-free areas (Figure 8). The core of meshes or bastites recrystallized at high grade with interpenetrative serpentine blades (Figure 8). Textural evidences coupled to a micro-Raman spectroscopic study show that antigorite is the main variety, as expected by its stability under high pressures (Auzende et al., 2005). Antigorite grains show no apparent compositional variation with low $\mathrm{Al}_{2} \mathrm{O}_{3}$ and $\mathrm{Fe}_{2} \mathrm{O}_{3}$ $(<2 \mathrm{wt} \%$. Lizardite and chrysotile form secondary veins during retrogression.

Microstructure of antigorite was investigated by electron imaging coupled to SAED with a transmission electron microscope (Auzende et al., 2005). The results show that antigorite 
crystals display similar texture and compositions. However, all studied SAED patterns show sharp modulation diffraction spots without streaking in the $\mathbf{a}^{*}$ direction (Figure 9). The evidence suggests intracrystalline polysomatic regularity in Monviso samples with the constant $A$ dimension (modulation wavelength). This regularity is also apparent on TEM images, showing a highly ordered structure along a. Nevertheless, while the modulation length is constant in each crystal, this dimension significantly varies from one antigorite grain to one another within the same TEM preparation.

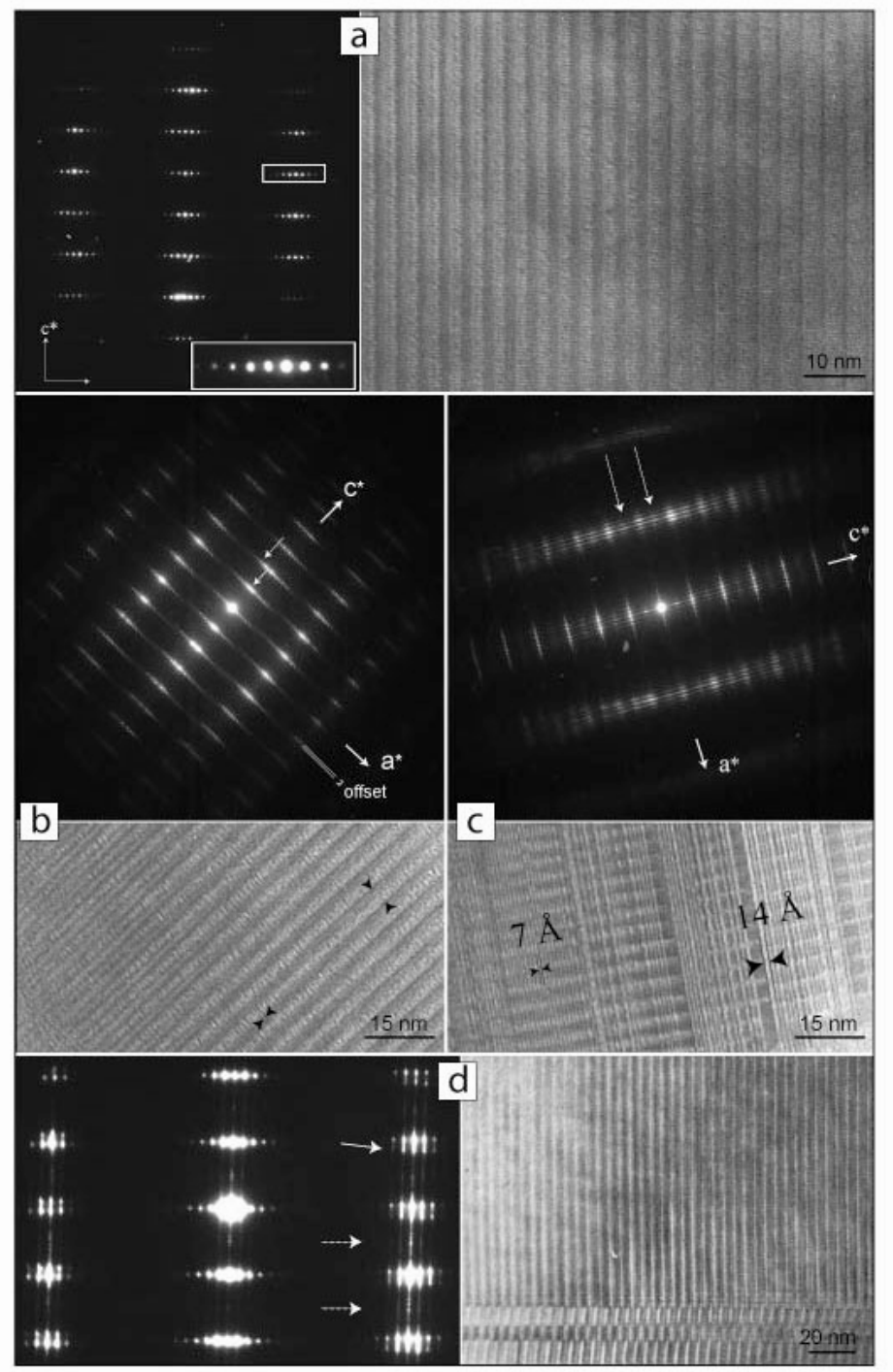

Figure 9. Electron micrographs and SAED patterns of antigorite crystals from Monviso oriented along [010] direction (after Auzende et al., 2005). a) Highly ordered structure along a* and $\mathrm{c}^{*}$. . b) Offset structure. The offset is the deviation between the alignment of satellites around a $(h 00)$ sublattice spot and that of the neighbouring (h00) group (Passo Gallarino, 624-7), c) Stacking variations, alternating 1- and 2-layer polytypes. The dashed arrows in the SAED pattern point at the intensity reinforcement due to the double periodicity along $c^{*}$. Besides the polytypic variations, the pattern shows diffuse streaks which affect the lattice and modulation spots along c*, indicating the loss of periodicity due to planar faults (Passo Gallarino, 624-7), d) Streaking along $\mathrm{c}^{*}$ indicates stacking disorder. White arrow shows spot rotation due to twinning and dotted white arrows indicate supplementary diffraction spot with $14.6 \AA$ A periodicity showing 2-layer polytypism (Monviso, Lago Superiore, 623-3). 
The modulation wavelength is commonly expressed by the $m$-value, as the number of tetrahedra in one modulation. According to our data from SAED patterns of the 96 antigorite crystals oriented along [010], antigorites from Monviso have $m$-values varying between 16 and 20 (41 to $52 \AA$ ), with a dominance of crystals with $m=18$ (46 $\AA$ ) and 19 (49 $\AA$ ) (Figure

9 ). The average $m$-values for the three units are close considering their standard deviation.

\section{Timing and mechanism of exhumation}

As previously mentioned, the Monviso unit is generally considered as a fragment of the Upper Jurassic Tethyan oceanic lithosphere, subducted at the Paleocene-Eocene boundary (Lagabrielle and Cannat, 1990). However, the eclogites show metamorphic pressures varying from 1.2 GPa to 2.4 GPa independent of the size of blocks from decimetres to kilometres (Messiga et al., 1999; Schwartz et al., 2000; Castelli et al., 2002). This suggests that the Monviso massif does not represent a continuous fragment of the Tethyan lithosphere. Instead, it is an assemblage of tectonically juxtaposed slices that were subducted to different depths. Furthermore, PT conditions of different units do not show any logical arrangement (Figure 6), suggesting that this tectonic juxtaposition unlikely took place during the exhumation. Finally, the basal unit, records variable P-T conditions from a minimum of $1.3 \mathrm{GPa}$ and $470{ }^{\circ} \mathrm{C}$ to 2.0 GPa and $575^{\circ} \mathrm{C}$ (Blake et al., 1995; Schwartz et al., 2000; Castelli et al., 2002). The evidence collectively concludes that the Monviso is a tectono-metamorphic melange with variable eclogitic blocks in a serpentinite matrix. Our proposed interpretation is supported by numerical modelling by Gerya et al. (2002) and Stöckert and Gerya (2005) which showed that a subduction channel with low viscosity $\left(\sim 10^{19}\right.$ Pa.s) favoured the formation of a large melange. If the Monviso massif represents the exhumed part of a subduction channel, the varied ages of eclogites between $61 \pm 10 \mathrm{Ma}$ and $45 \pm 1$ Ma may be related to the different blocking temperatures of isotope systems. This is a long standing problem in metamorphic rocks (Monié and Chopin, 1991; Arnaud and Kelley, 1995; Rubatto and Hermann, 2003). Alternatively, these ages may signify different events in the serpentinized channel. This may be supported by the fact that these ages do not overlap each other. Thus, we favour the latter interpretation. In this case, it gives a duration of the serpentinized channel of 5 to $15 \mathrm{Ma}$.

The exhumation of rocks requires a mechanically weak zone at the interface between the subducting plate and overlying mantle peridotites (Cloos, 1982; Closs and Schreeve, 1989, Platt, 1993; Allemand and Lardeaux, 1997). At the depth greater than 40-50 km, hydrated peridotites can play the role of lubricant (Hermann et al., 2000; Guillot et al., 2000; Gerya et al., 2002). The exhumation of dense eclogitic block (> $3500 \mathrm{~kg} . \mathrm{m} 3)$ in a buoyant serpentinite matrix ( $<2700$ kg.m3) requires a dynamic return flow (corner flow). Assuming a Newtonian rheology of serpentinites in subduction conditions (Gerya and Stöckert, 2002; Auzende et al., 2005), the velocity and the size of the exhumed eclogitic blocks are controlled by a Stoke's law (Cloos, 1982). In our previous paper (Schwartz et al., 2001) we have numerically evaluated the possibility that the eclogitic blocks similar to those in the Monviso can be exhumed in a low viscosity channel (Figure. 10). The exhumation of decimetric to kilometric eclogitic block at a velocity of one $\mathrm{cm} / \mathrm{yr}$ requires the low viscosity channel of about $10 \mathrm{~km}$ width and a minimum viscosity of $10^{20}$ Pas. The viscosity is similar to the result obtained by Guillot et al., (2001) and Stöckert and Gerya (2005). The viscosity imposes that the channel is composed of partially (up to 50\%) hydrated peridotites.

Our proposed interpretation is supported by the geophysical evidence for $10 \mathrm{~km}$ thick hydrated peridotites layer along Pacific subduction zones (Bostock et al., 2002; Billen and Gurnis, 2003; Seno and Yamasami, 2003). The cross section of the Monviso (Figure 4) suggests that the serpentinite subduction channel had the minimum thickness of $4 \mathrm{~km}$. The total length of this channel is difficult to estimate, but may be 40 to $50 \mathrm{~km}$ long if the Monviso massif extends beneath the Dora Maia massif and has a depth of $10 \mathrm{~km}$ on its 
western part (Paul et al., 2001) (Figure 4). The first assumption is supported by geophysical data farther north of the study area (Escher et al., 1997).
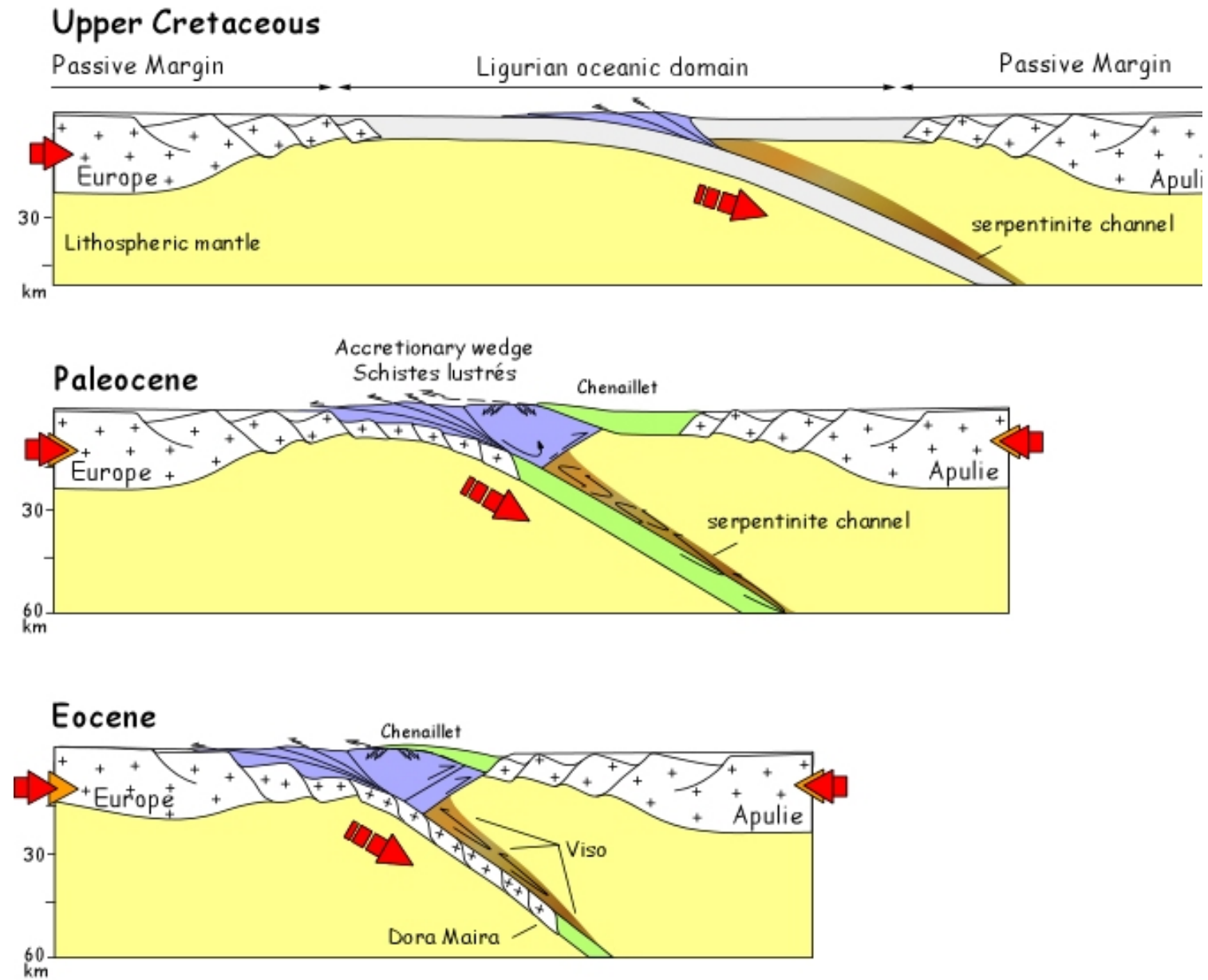

Figure 10. Schematic evolution of the Piedmont subduction zone from Upper Cretaceous to Eocene. The Schistes Lustres accretionary wedge is separated from the serpentinite channel overlying the subduction zone. Note that the serpentine channel records internal motions during the Paleocene, whereas, the initiation of the subdcution of the Continental European margin in Eocene time stopped the activity inside the subduction channel, leading to the final exhumation of the Monviso eclogitic blocks.

The length of the subduction channel is estimated using the PT conditions of eclogitic fragments in the Monviso massif. If the massif is a tectonic melange, different eclogitic blacks record the pressures of the subduction channel. The pressure difference of $1.2 \mathrm{GPa}$ between 
the highest pressure unit (2.4 GPa, Lago Superior) and the lowest pressure unit (1.2 GPa, Passo Galarino) corresponds to a depth difference of $\sim 40 \mathrm{~km}$.

A question remains the relationship between the southeast dipping subduction of the European continent margin and the exhumation of the eclogitized oceanic crust (e.g. Agard et al., 2002 for a complete discussion). Polino et al. (1990) and Allemand and Lardeaux (1997) proposed that the burial and the subsequent exhumation of the oceanic plate occurred only during active subduction whereas other authors proposed that the main exhumation of oceanic plate occurred when the buoyant continental margin subducted (Chemenda et al., 1996; Ernst, 2001). In contrast, Rosenbaum and Lister (2005) proposed a collisional event at $45 \mathrm{Ma}$.

The relationship between the exhumation and continental subduction is clear north of the study area along a Gran Paradiso Zermatt-Saas transect. The HP metamorphism in Zermatt-Saas ophiolite is dated at $40.6 \pm 0.6 \mathrm{Ma}$ by Sm-Nd isotopes whereas the HP metamorphism of the European continent at the Gran Paradiso massif is estimated to have occurred at a $43.0 \pm 0.5 \mathrm{Ma} \mathrm{Rb}-\mathrm{Sr}$ isochron based on microsampling. The data suggest that HP metamorphism was synchronous. Stöckhert and Gerya (2005) also show by numerical simulation that the peak of metamorphism in the Internal Alps is probably contemporaneous for continental and oceanic units, 10 to $20 \mathrm{Ma}$ after their initial subduction of the European continent. In the Monviso area, the relationship between oceanic and continental subdution is not so clear. In fact, the HP metamorphism in the Monviso ophiolite occurred between 60 to 45 Ma whereas the UHP metamorphism in the nearby continental unit of Dora Maira is dated between 31 and 35 Ma (Duchêne et al., 1997; Gebauer et al., 1997; Cliff et al., 1998; Rubatto and Hermann, 2001). We can assume than the subduction and subsequent exhumation of the Monviso massif occurred before the continental subduction of the Dora Maira continental massif (Figure 10). However, a low convergence rate, about 6-8 mm.yr-1, of the Western Tethys from Late Cretaceous to Eocene (Facenna et al., 2001; Schettino and Scotese, 2002) suggests a minimum of $17 \mathrm{Ma}$ for the Dora Maira massif to reach the depth of $120 \mathrm{~km}$ for the UHP metamorphic conditions. This implies that the continental subduction initiated before 45-50 Ma in the studied area, i.e. at the time of the HP metamorphism in the Monviso unit. Thus we conclude that the exhumation of the Monviso massif is broadly contemporaneous as the continental subduction of the Dora Maira massif (Figure 10).

\section{Conclusion}

The Monviso ophiolitic massif in the Western Alps is one of the best exposed subduction channels of serpenites. As has been suggested for over 30 years, metamorphosed mafic igneous rocks in the Monviso ophiolite are originally oceanic basalts formed at the slow spreading ridge on the western Tethys ocean floor. The origin of the serpentinites remains partly unclear, but the majority of serpentinites are likely derived from oceanic lherzolites. Some refractory harzburgites at the basal unit may have derived from the mantle wedge overlying the subduction plate, as observed in Himalaya and present day observed along Pacific subduction zone. The serpentinites are completely recrystallized under HP conditions as only the high grade antigorite specimen of serpentine is observed. The low viscosity of serpentinites favours the formation of a low viscosity subduction channel $\left(10^{19}-10^{20}\right.$ Pa.s $)$ where $\mathrm{cm}$ to kilometric blocs of eclogitized oceanic crust are incorporated at different depths and exhumed together up to blueschis facies conditions along a 40-50 km long subduction channel with a width of 4 to $10 \mathrm{~km}$. The time difference between the different units of 5 to 15 Ma may reflect the minimum life span of serpentinite subduction channel. Finally we propose that this serpentinite subduction channel ended when the continental subduction started at about 45-40 Ma. 


\section{Acknowledgment}

This work was supported by the INSU-CNRS programs "Intérieure de la Terre", DYETI and the BRGM-INSU-CNRS program "GéoFrance 3D".

\section{References}

Agard, P., P. Monié, et al. (2002). "Exhumation of the Schistes Lustrés complex: in situ laser probe $\mathrm{Ar} / \mathrm{Ar}$ constraints and implications for the Western Alps.” Journal of Metamorphic Geology 20: 599-618.

Allemand, P. and J. M. Lardeaux (1997). "Strain partioning and metamorphism in a deformable orogenic wedge: application to the Alpine belt.” Tectonophysics 280: 157169.

Amato, J. F., C. M. Johnson, et al. (1999). "Rapid exhumation of the Zermatt Saas ophiolite deduced from high precison Sm-Nd and Rb-Sr geochronology.” Earth and Planet Science Letters 171: 425-438.

Arnaud, N. O. and S. P. Kelley (1995). "Evidence for excess argon during high pressure metamorphism in the Dora Maira Massif (western Alps, Italy), using an ultra-violet laser ablation microprobe ${ }^{40} \mathrm{Ar}^{39} \mathrm{Ar}$ technique.” xxxxxx121: 1-11.

Mis en forme : Anglais (Royaume-Uni)

Auzende, A. L., Devouard, B., Guillot, S., Daniel, I.Baronnet, A., Lardeaux, J.M. (2002). "Serpentinites from Central Cuba: petrology, and HRTEM study." European Journal of Mineralogy 14: 905-914.

Auzende, A. L., S. Guillot, et al. (2005). "Behavior of serpentinites in convergent context: microstructural evidences.” European Journal of Mineralogy in press.

Ballèvre, M., Y. Lagabrielle, et al. (1990). "Tertiary ductile normal faulting as a consequence of lithospheric stacking in the Western Alps.” Société Géologique de France, mémoires 156: 227-236.

Billen, M. I. and M. Gurnis (2003). "Comparison of dynamic flow models for the Central Aleutian and Tonga-Kermadec subduction zones." Geochemistry Geophysics Geosystems 1035 doi:10 1029/2001GC000295.

Blake, C. and A. S. Jayko (1990). "Uplift of high pressure rocks in the Western Alps: evidence of structural attenuation along low angle normal faults.” Mémoire de la Socièté Géologique de france 156: 228-237.

Blake, C., D. G. Moore, et al. (1995). "The role of the serpentinite melange in the unroofing of the UHP rocks: an example from the western Alps in Italy.” from Coleman R.G. and Wang X. (eds). Ultrahigh pressure metamorphism. Cambridge University Press: 182205.

Bostock, M. G., and. Hydman, R.D., et al. (2002). "An inverted contienntal Moho and serpentinization of the forearc mantle.” Nature 417: 536-538.

Castelli, D., C. Rostagno, et al. (2002). "Jd-QTZ-bearing metaplagiogranite from the Monviso meta-ophiolite (Western Alps).” Ofioliti 27: 81-90.

Chemenda, A. I., M. Mattauer, et al. (1996). "Continental subduction and a mechanism for exhumation of high-pressure metamorphic rocks: new modeling and field data from Oman.” Earth Planetary Science Letters 143: 173-185.

Chopin, C. and H. B. Schertl (1999). "The UHP unit in the Dora Maira massif, western Alps.” International Geology Reviews 41: 765-780.

Cliff, R. A., Barnicoat, A.C. and Inger,S. (1998). "Early Tertiary eclogite facies metamorphism in the Monviso Ophiolite.” Journal metamorphic geology 16: 447-455. 
Cloos, M. (1982). "Flow melanges : numerical modelling and geological constraints on their origin in the Franciscan subduction complex." Geological Society of America Bulletin 93: 330-345.

Cloos, M. and R. L. Shreve (1988). "Subduction channel model of prism accretion, melange formation, sediment subduction, and subducting erosion at convergent plate margins: 1 . Background and description, in subduction zone Part 1.” Pageophysics 128: 501-545.

de Sigoyer, J., S. Guillot, et al. (2004). "Exhumation Processes of the high-pressure lowtemperature Tso Morari dome in a convergent context (eastern-Ladakh, NWHimalaya).” Tectonics Vol. 23, No. 3, TC3003 - 10.1029/2002TC001492.

Deville, E. (1986). "La klippe de la pointe du grand Vallon (Vanoise, Alpes Occidentales): un lambeau de métasédiments à foraminifères du Maastrichien Supérieur couronnant les nappes de Schistes Lustrés.” Compte-rendus de l'Académie des Sciences 303: 12111226.

Deville, E., S. Fudral, et al. (1992). "From oceanic closure to continental collision: a synthesis of the Schistes Lustrés metamorphic complex of the Western Alps.” Geological Society of America 104: 127-139.

Duchêne, S., J. Blichert-Toft, et al. (1997a). "The Lu-Hf dating of garnets and the ages of the Alpine high-pressure metamorphism.” Nature 387: 586-589.

Duchene, S., J. M. Lardeaux, et al. (1997). "Exhumation of eclogites: Insights from retrograde depth-time path analysis.” Tectonophysics 280: 125-140.

Duchêne, S., J. M. Lardeaux, et al. (1997). "Exhumation of eclogites: insights from depthtime path analysis." Tectonophysics 280.

Eide, E. A. and J. G. Liou (2000). "High Pressure blueschists and eclogites in Hong'an: a framework for adressing the evolution of high and ultrahigh-pressure rocks in central China.” Lithos 52: 1-22.

Ernst, W. G. (2001). "Subduction, ultrahigh-pressure metamorphism, and regurgitation of buoyant crustal slices - implications for arcs and continental growth.” Physical of Earth Planetary Interior 127: 253-275.

Escher, A., J. Hunziker, et al. (1997). "Geologic framework and structural evolution of the Western Swiss-Italian Alps.” In Pfinner O.A., Lehner, P., Heitzmann, P., Mueller, S., Steck (Eds). Deep structure of the Swiss Alps. Results of NRP 20. Birkhäusser Verlag, basel.: 205-211.

Facenna, C., T. W. Becker, et al. (2001). "History of subdcution and and back arc extension in the central Mediterranean.” Geophysical Journal Interiors 145: 809-820.

Garcia-Casco, A. G., R. L. Torres-Roldan, et al. (2002). "Oscillatory zoning in eclogitic garnet and amphibole northern serpentinite melange, Cuba: a record of tectonic instability.” Journal of Metamorphic Geology 20: 581-598.

Gebauer, D., H. B. Schertl, et al. (1997). "35 Ma old ultra-high pressure metamorphism and evidence for very rapid exhumation in the Dora Maira massif, Western Alps.” Lithos 41: 5-24.

Gerya, T. V. and B. Stöckert (2002). "Exhumation rates of high pressure metamorphic minerals in subduction channels: the effect of rheology.” Geophysical Research Letters 29: 102-1 TO 102-4.

Gerya, T. V., B. Stöckert, et al. (2002). "Exhumation rates of high pressure metamorphic minerals in subduction channels: a numerical simulations.” Tectonics 21: 1056, doi:10.1029/2002TC001406.

Goncalvez, P., S. Guillot, et al. (2000). "Thrusting and sinistral wrenching in a pre-Eocene carribean accretionary wedge (Samana pensinsula -Dominican Republic).” Geodinamica Acta 13: 119-132. 
Guillot, S., E. Garzanti, et al. (2003). "Reconstructing the total shortening history of the NW Himalaya.” Geochem. Geophys. Geosyst., 4(1), XXXX, doi:10.1029/2002GC000484.

Guillot, S., K. Hattori, et al. (2000). "Mantle wedge serpentinization and exhumation of eclogites: insights from eastern Ladakh, northwest Himalaya.” Geology 28: 199-202.

Guillot, S., K. Hattori, et al. (2001). "Evidence of hydration of the mantle wedge and its role in the exhumation of eclogites." Earth and Planetary Sciences Letters 193: 115-127.

Hacker, B. R., L. Ratschbacher, et al. (2000). "Exhumation of ultrahigh-pressure continental crust in east central China; Late Triassic-Early Jurassic tectonic unroofing.” Journal of Geophysical Research, B, Solid Earth and Planets 105(6): 13,339-13,364.

Hermann, J., O. Müntener, et al. (2000). "The importance of serpentinite mylonites for subduction and exhumation of oceanic crust.” Tectonophysics 327: 225-238.

Hirth, G. and D. Kohlstedt (2003). "Rheology of the upper mantle and the mantle wedge: a view from the experimentalists." Geophysical Monograph Series,Inside the Subduction Factory 138: 83-105.

Labrousse, L., L. Jolivet, et al. (2002). "Crustal scale boudinage and migmatization of gneiss during their exhumation in the UHP province of Western Norway.” Terra Nova 14: 263270.

Lagabrielle, Y. and M. Cannat (1990). "Alpine Jurassic ophiolites resemble the modern central Atlantic basement.” Geology 18: 319-322.

Lagabrielle, Y. and a. others (1984). "Les témoins d'une tectonique intraocéanique dans le domaine téthysien: analyse des rapports entre les ophiolites et leur couverture métasédimentaire dans la zone piédmontaise des Alpes Franco-Italiennes.” Ofioliti 9: 67-88.

Le Fort, P., S. Guillot, et al. (1997). "HP metamorphic belt along the Indus suture zone of NW Himalaya : new discoveries and significance.” Compte Rendus de l'Académie des Sciences, Paris 325: 773-778.

Lemoine, M., P. Tricart, et al. (1987). "Ultramafic and gabbroic ocean floor of the Ligurian Tethys (Alps, Corsica, Apennines): in search of a genetic model.” Geology 15: 622-625.

Li, X. P., M. Rahn, et al. (2004). "Serpentinites of the Zermatt-Saas ophiolite complex and their texture evolution.” Journal of Metamorphic Geology 22: 159-177.

Lombardo, B., R. Nervo, et al. (1978). "Osservazioni preliminari sulle ofioliti metamorfiche del monviso (Alpi occidentali).” Rendiconti Societa Italiana di Mineralogia e Petrologia 34: 253-305.

Lombardo, B., D. Rubatto, et al. (2002). "Ion microprobe U-Pb dating of zircon from a Monviso metaplagiogranite: implications for the evolution of the Piedmont-Liguri Tethys in the western Alps.” Ofioliti 27: 109-117.

Meffan-Main, F., R. A. Cliff, et al. (2004). "A Tertiary age for Alpine metamorphism in the Gran Paradiso massif, western Alps: a Rb-Sr microsampling study.” Journal of Metamorphic Geology 22: 267-281.

Messiga, B., J.-R. Kienast, et al. (1999). "Cr-rich magnesio-chloritoid eclogites from the Monviso ophiolites (Western Alps, Italy).” Journal of Metamorphic Geology 17: 287299.

Mevel, C. (2003). "Serpentinization of abyssal peridotites at mid-ocean ridges." Comptes Rendus Géoscience 335: 825-852.

Mevel, C., R. Caby, et al. (1978). "Lower amphibolite facies conditions in the oceanic cruts: example of amphibolitized falser-gabbro and amphibolites from an alpine ophiolitic massif (Chenaillet massif, Hautes Alpes, France).” Earth and Planet Science Letters 39: 98-108.

Monie, P. and C. Chopin (1991). "Ar dating in coesite-bearing and associated units of the Dora Maira massif, Western Alps.” Eur.J.Mineral. 3: 239-262. 
Monié, P. and P. Philippot (1989). "Mise en évidence de l'âge Eocène moyen du métamorphisme de haute pression dans la nappe ophiolitique du Monviso (Alpes Occidentales) par la méthode Ar-Ar.” Compte-rendus de l'Académie des Sciences 309: 245-251.

Nadeau, S., P. Philippot, et al. (1993). "Fluid inclusion and mineral isotopic composition (H$\mathrm{C}-\mathrm{O}$ ) in eclogitic rocks as tracers of local fluid migration during high pressure metamorphism.” Earth and Planet Science Letters 114: 431-448.

Paul, A., M. Cattaneo, et al. (2001). "A three-dimensional crustal velocity model of the southwesternAlps from the local earthquake tomography.” Journal Geophysical Research 106: 19367-19389.

Philippot, P., P. Agrinier, et al. (1998). "Chlorine cycling during subduction of altered crust.” Earth and Planetary Science Letters 161: 33-44.

Piccardo, G. B., E. Rampone, et al. (2001). "Evolution of the Ligurian Tethys: inference from petrology and geochemistry of the Ligurian Ophiolites." Per. Mineralogy 70: 147-192.

Platt, J. P. (1986). "Dynamic of orogenic wedges and the uplift of high-pressure metamorphic rocks.” Bulletin of Geological Society of America 97: 1037-1053.

Platt, J. P. (1993). "Exhumation of high-pressure metamorphic rocks : a review of concepts and processes." Terra Nova 5: 119-133.

Polino, R., G. V. Dal Piaz, et al. (1990). "Tectonic erosion at the Adria margin and accretionary processes for the Cretaceous orogeny of the Alps.” Mémoire de la Socièté Géologique de France 156: 345-367.

Rosenbaum, G. and G. S. Lister (2005). "The Western Alps from the Jurassic to Oligocene: spatio-temporal constraints and evolutionary reconstructions.” Earth Science Reviews 69: 281-306.

Rubatto, D. and J. Hermann (2001). "Exhumation as fast as subduction ?” Geology 29: 3-6.

Rubatto, D. and J. Hermann (2003). "Zircon formation during fluid circulation in eclogites (Monviso Western Alps): implications for $\mathrm{Zr}$ and $\mathrm{Hf}$ budget in subduction zones.” Geochimica and Cosmochimica Acta 67: 2173-2187.

Scambelluri, M., O. Muntener, et al. (1995). "Subduction of water into the mantle: history of an alpine peridotite.” Geology 23: 459-462.

Schettino, A. and C. Scotese (2002). "Global kinematic constraints to the tectonic history of the mediterranean region and surrounding areas during the Jurassic and Cretaceous." Journal of Virtual Explorer 8: 145-160.

Schwartz, S. (2001). La zone piémontaise des Alpes occidentales: un paléo-complexe de subduction; arguments métamorphiques, géochronologiques et structuraux. Documents du BRGM, vol. 302, 313 pp.

Schwartz, S., P. Allemand, et al. (2001). "Numerical model of the effect of serpentinites on the exhumation of eclogitic rocks : insights from the Monviso ophiolitic massif (Western Alps).” Tectonophysics 42: 193-206.

Schwartz, S., J. M. Lardeaux, et al. (2000). "Diversité du métamorphisme éclogitique dans le massif ophiolitique du Monviso 'Alpes Occidentales, Italie).” Geodinamica Acta 13: 169-188.

Seno, T. and T. Yamasaki (2003). "Low frequency tremors, intraslab and interplate earthquakes in southwest Japan, from a viewpoint of slab dehydration." Geophysical Research Letters 30: 22 2171- doi 10.1029/2003GLO18349.

Stöckert, B. and T. V. Gerya (2005). "Pre-collisional HP metamorphism and nappe tectonics at active continental margins: a numerical simulation.” Terra Nova doi10.1111/j.13653112.2004.00589.

Stöckert, B., M. Wachmann, et al. (1999). Tectonophysics 303: 299-319. 
Tricart, P., S. Schwartz, et al. (2004). "Evidence for synextensional tilting and doming during during final exhumation from analysismultistage faults (Queyras, Schsites Lustrés, Western Alps).” Journal of Structural Geology 26: 1633-1645.

Vidal, O., T. Parra, et al. (2001). A thermodynamic model for Fe-Mg aluminous chlorite using data from phase equilibrium experiments and natural pelitic assemblages in the100$600^{\circ} \mathrm{C}, 1-25$ kbar P-T range. American journal of Science, 301, 557-592. 